\title{
The PRI Apple Breeding Program
}

\author{
Jules Janick \\ Department of Horticulture and Landscape Architecture, Purdue University, West Lafayette, IN 47907-1165
}

\section{ORIGINS}

The PRI cooperative scab-resistant apple breeding program between Purdue University, Rutgers, The State University of New Jersey, and the University of Illinois has a long and interesting history involving many scientists and collaborators (D.F. Dayton, "A history of the Illinois-Indiana-New Jersey cooperative apple breeding program," unpublished; Crosby etal., 1992; Janick, 2002). The original program dates to a formal 1945 collaboration between J. Ralph Shay(1918-1980), pathologist at Purdue University, and L. Fredric Hough (1915-1993), horticulturist at the University of Illinois, to develop scab-resistant apples. Shay was a man of vision who was enthusiastic about his work and about science in general. He had an outgoing personality, made friends easily, and had the ability to stimulate enthusiasm in others. Hough was an extraordinary fruit breeder, full of optimism, whose credo of "one more generation" typified his philosophy of fruit breeding, which was to cherish diversity, pollinate with abandon, and extravagantly share seedlings with everyone. Pollination was his happiest time as he, with carloads of students, pursued Spring in her northward trek in an attempt to improve the odds for favorable recombinants - always just a generation away. Interestingly, the PRI program was initiated before the environmental implications of pesticides were realized, and the goal was simply one of serving the needs of fruit growers.

The germplasm exploited by Shay and Hough can be traced to breeding studies of C.S. Crandall (1852-1929) at the University of Illinois carried out as early as 1907. Crandall had assembled a large collection of Malus species and forms at the beginning of the century and initiated an intensive study of crosses between cultivated apples and crab-like forms. A summary of Crandall's work, published in University of Illinois Bulletin 275 (Crandall, 1926), describes all the material in the program. Crandall, influenced by the rediscovery of Mendel, was attempting to determine inheritance patterns in Malus. Ironically, he did not work with characteristics that would enable him to identify single genes or evaluate his material for disease resistance. The voluminous data he collected and maintained at the University of Illinois has never been completely analyzed, although the designations reported in Bulletin 275 describing his species sources have become justly famous. The selection he labeled Malus floribunda 821 was the original source of the $V_{f}$ gene. Fortunately, his breeding material was maintained following his retirement in 1927 , but remained unevaluated until L.F. Hough joined the department in 1942 as a graduate student and plant-breeding assistant.

Spring 1943 was unusually cool and wet, resulting in a severe epidemic of scab that defoliated all susceptible unsprayed apples trees. Hough noted that one progeny, an $\mathrm{F}_{2}$ of $M$. floribunda $821 \times$ Rome Beauty, segregated at a ratio of 1 resistant : 1 susceptible, suggesting the involvement of a single gene, later termed $V_{f}$. Hough published his results with the Proceedings of the American Society of Horticultural Science in his famous paper "A Survey of the Scab Resistance of the Foliage of Seedlings in Selected Apple Progenies" (Hough, 1944). The paper was brought to the attention of J.R. Shay, ayoung professor whojoined the Purdue's Department of Botany and Plant Pathology from Arkansas and who had received his $\mathrm{PhD}$ from the University of Wisconsin where a program on the pathogenicity of Venturia inaequalis had been underinvestigation. (In the 1940s, considerable interest in the genetics of the ascomycetes had been engendered by the work of Beadle and Tatum in Neurospora.) Shay and Hough decided to collaborate on a scab-resistance breeding program with the objective to advance genetic resistance identified by Hough into improved horticultural backgrounds and identification of additional resistant Malus germplasm through testing of material in arboreta and other collections. The first screened hybrid progenies were planted in the field in 1947 and began fruiting at Illinois in 1951. A formal cooperative program was established in 1945 between the agricultural experiment stations associated with Purdue University and the University of Illinois.

\section{THE TEAM}

In 1948, Hough moved to the Department of Horticulture and Forestry at Rutgers, The State University of New Jersey, and, shortly thereafter, Rutgers joined Illinois and Purdue as the third partner in the collaboration, thereby making available to the program a large volume of valuable susceptible apple germplasm developed by the late M.A. Blake. In 1950, Daniel F. Dayton joined the program at Illinois while pursuing graduate studies. Dan was a witty, energetic New Englander from New Hampshire who was equally at home in the orchard as improvising on the organ. Edwin B. Williams, a graduate student of Shay's in plant pathology, a native Hoosier, and a World War II veteran who had served in the Philippines, became a skilled pomologist to complement his abilities as a pathologist, fisherman, and poker player. Dayton and Williams remained with the program upon completion of their PhD degrees (Fig. 1). Dayton continued leadership for the Illinois

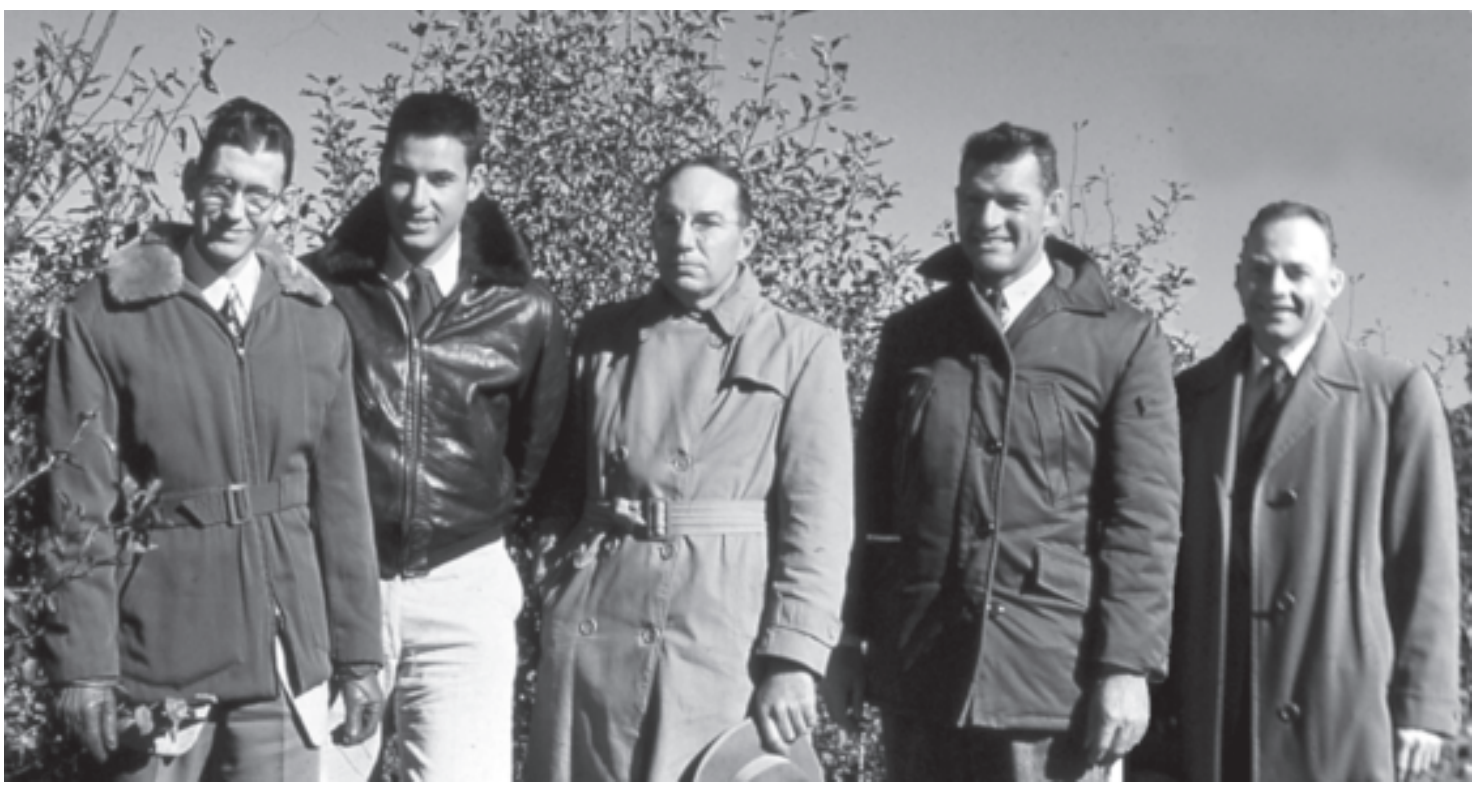

Fig. 1. Dan Dayton, Jules Janick, Ed Williams, Fred Hough, and Ralph Shay (left to right). 
Table 1. Defined gene pools for resistance to apple scab.

\begin{tabular}{ll}
\hline Symbol & Original Malus source \\
\hline$V_{f}$ & M. floribunda \\
$V_{m}$ & M. micromalus (pit) \\
$V_{r}$ & M. pumila (Russian) 12740-7A \\
$V_{\mathrm{bj}}$ & (probably M. seversia) \\
$V_{b}$ & M. baccata jackii \\
$V_{a}$ & Hansens's baccata \#2 \\
\hline
\end{tabular}

team, with Williams assuming leadership of the Purdue program when Shay left to join the University of Oregon in 1966. J.B. Mowry, stationed at the Illinois Horticultural Experiment Station, Carbondale, joined the collaboration in 1952 and tested material until his death in 1986. In 1955, Catherine H. Bailey, a graduate student of Hough and research associate, became a participant at Rutgers. I joined the Purdue program in 1954 and, by a curious set of circumstances, became the last man standing of the original PRI group (Fig. 1). Frank $\mathrm{H}$. Emerson was a part of the program from 1967 to 1988 . Schuyler S. Korban replaced Dayton at the University of Illinois upon his retirement in 1982. Shawn A. Mehlenbacher replaced Hough after his retirement in 1981, remained with the program from 1982-1986, and was in turn replaced by Joseph Goffreda in 1989. Other participants in PRI included Jeffry A. Crosby and Paul C. Pecknold at Purdue University, P.A. O'Connor and S.M. Ries at the University of Illinois, and A. Voordeckers at Rutgers University. H.F. Goonewardene, aU.S. Department of Agriculture employee stationed at Purdue, investigated insect resistance in PRI germplasm from 1973 to 1988.

\section{TECHNIQUES AND STRATEGY}

Techniques for controlled greenhouse screening of hybrid progenies were developed by Shay, thus making it possible to identify resistant segregates within 2 months after seed germination. Resistance of apple to scab was scored according to symptoms on young leaves grown under greenhouse conditions: $0=$ no macroscopic evidence of infection; 1 = pinpoint pits, no sporulation; 2 = irregular chlorotic or necrotic lesions and no sporulation; $3=$ few restricted sporulating lesions; and $4=$ extensive, abundantly sporulating lesions. The class $\mathrm{M}$ was added to indicate a mixture of necrotic, nonsporulating, and sparsely sporulating lesions (Shay and Hough, 1952). Only class 4 was considered as field-susceptible; all the others classified as field-resistant and did not show symptoms of infection when grown outdoors where conditions for scab are very favorable. Using a broad definition of resistance, crosses of heterozygous-resistant with homozygous-susceptibles segregate 1 resistant : 1 susceptible but usable resistance (completely nonsporulating, i.e., class 0,1 , and 2 ) is lower, typically $30 \%$. For example, although $V_{f}$ is traditionally considered to be a simply inherited, dominant factor conditioning qualitative resistance, it is often associated with any number of quantitative resistance factors that make it less vulnerable to attack by new races of the fungus. Progeny segregation ratios and the frequency distribution of leaf reaction classes suggest the complexity of the genetic basis of resistance derived from $V_{f}$.

The goals of the program were 2-fold: genetic improvement of apple and an elucidation of the genetics of resistance in apple. The breeding strategy consisted of a modified backcross program with the entire spectrum of susceptible cultivars serving as recurrent parents. Several Malus species were used to incorporate their resistance factors into more advanced pomological backgrounds. The extensive effort to evaluate the nature of resistance and the stability of resistance was carried out in studies parallel to the breeding program. Many Malus species and hybrids with genetic resistance useful in breeding were subsequently identified. Through a series of intercrosses (tests of allelism) it was established that 11 of the 25 sources were due to the same $V_{f}$ gene (Williams and Kuc 1969). Six loci for qualitative resistance(defined gene pools) were identified as shown in Table 1.

Five different virulent races of $V$. inaequalis were identified, and race 6 has been subsequently identified in Germany (Parisi et al., 1993) as shown in Table 2. Recently, race 7 has appeared and attacks M. floribunda 821 and questions the durability of the $V f$ gene without modifiers. Fortunately race 7 does not attack 'Golden Delicious', which indicates the presence of modifiers in this cultivar (Y. Lespinasse, personal communication).

In addition to screening for apple scab, screening for other diseases was carried out in the field from natural infection. These included fireblight incited by Erwinia amylovora (Burr. A) Winslow et al., cedar-apple rust incited by Gymnosporangium juniperi-virginianae Schw., and powdery mildew incited by $\mathrm{PO}$ dosphaera leucotricha (Ell. \& Ev.) Salm. Some screening for mildew was carried out in
England under the assistance of the late A.G. Brown of the John Innes Institute.

The original breeding program was uniquely a true cooperative effort between the three stations. While crossing was carried out at each location, the bulk of the successful hybridizations were achieved by Hough, who each spring traveled with his team of pollinators from New Brunswick, N.J., to Geneva, N.Y., and on to New Hampshire, following spring in its northern trek. All seeds were assembled at Purdue University and screened for scab at the Department of Botany and Plant Pathology. Resistant seedlings were either planted directly to the field or grown in a nursery and then divided between cooperators, with the bulk of the progenies evaluated in Indiana and Illinois. Fruit of promising seedlings each year were compared in a joint display and used in crosses in the following years. By 1967 the most promising selections, called co-ops to underscore the cooperative nature of the program, were released to interested testers including fruit growers and experiment stations in other states. In addition, promising selections were shared worldwide with international cooperators.

\section{ACCOMPLISHMENTS}

Up to the present time, more than 1500 selections have been made of which 44 have been released for advanced testing as coops, and, of these, 16 have been named as shown in Table 3. Joint releases from other PRI selections include 'McShay' (1988), released in cooperation with Oregon State University;'Priam'(1974) and 'Juliet' (1999), released in France; 'Primiera' (1995), released in Italy; 'Primivera' (1996), released in Quebec, Canada; and 'Constance' (1995), released in Germany by an organic grower. 'Nambu' (1994) is a PRI selection that was released

Table 2. Races of Venturia inaequalis and differential hosts of apple.

\begin{tabular}{|c|c|c|}
\hline$\overline{\text { Race }}$ & Source & Susceptible material \\
\hline$\overline{1}$ & Worldwide & Most of the world's cultivars \\
\hline 2 & South Dakota & $\begin{array}{l}\text { M. baccata, 'Dolgo', 'Alexis', 'Bittercrab' segregates of } \\
\text { R12740-7A, 'Geneva' }\end{array}$ \\
\hline 3 & Nova Scotia, Canada & 'Geneva' \\
\hline 4 & Lafayette, Ind. & Segregates of R12740-7A \\
\hline 5 & Norwich, England & Micromalus pit type resistance, M. atrosanguinea 804 \\
\hline 6 & Ahrensburg, Germany & $\begin{array}{l}\text { 'Prima' (Vf cultivars) but not 'Evereste' } M . \times \text { 'Perpetu' } \\
\text { and } M . \text { floribunda } 821\end{array}$ \\
\hline 7 & England-Europe & M. floribunda 821 \\
\hline
\end{tabular}

Table 3. PRI and joint releases of scab-resistant apples.

\begin{tabular}{lccccc}
\hline PRI releases & Co-op no. & Year released & Joint releases & Co-op no. & Year released \\
\hline Prima & 2 & 1970 & Priam & --- & 1974 \\
Priscilla & 4 & 1972 & McShay & -- & 1988 \\
Sir Prize & 5 & 1975 & Primiera & 42 & 1995 \\
Jonafree & 22 & 1979 & Nambu & --- & 1994 \\
Redfree & 13 & 1981 & Constance & --- & 1995 \\
Dayton & 21 & 1988 & Primivera & --- & 1996 \\
Williams' Pride & 23 & 1988 & Juliet & 43 & 1999 \\
Enterprise & 30 & 1993 & & & \\
GoldRush & 38 & 1993 & & & \\
Pristine & 32 & 1994 & & & \\
Scarlett O'Hara & 25 & 2000 & & & \\
Pixie Crunch & 33 & 2004 & & & \\
Sundance & 29 & 2004 & & & \\
CrimsonCrisp & 30 & 2005 & & & \\
\hline
\end{tabular}


without authorization in Japan. 'Viking' (1969), released in Wisconsin, is a PRI selection but proved to be scab-susceptible.

An attempt was made to carry each source of resistance forward, but resistance derived from $M$. floribunda received the most attention because two $\mathrm{F}_{2}$ selections of the original $M$. floribunda $821^{2} \times$ Rome Beauty cross carrying the designation $\mathrm{F}_{2} 26829$ and $\mathrm{F}_{2} 28830$ were more advanced in size and quality. Selection $F_{2} 26829$, while only two generations from the original small-fruited species, had unusually good quality and was about $5 \mathrm{~cm}$ in diameter. A breakdown of the pedigrees of the 44 co-op selections indicates that all of the 44 released date back to $M$. floribunda, although Co-op 41 also has M. atrosanguinea 804 in its pedigree. Of the 43 floribunda selections, only one coop derived from 26830 entirely (Co-op 11), one has both $F_{2} 26829$ and $F_{2} 26830$ in its pedigree, and three have $\mathrm{F}_{2} 26829$ on both sides. The scab-resistance program at Cornell University originated from material derived from $F_{2} 26829$ and the two releases 'Liberty' and 'Freedom' carry the $V_{f}$ gene.

In 1963, the three cooperating universities, in conjunction with other interested American and Canadian breeders, formed a loose cooperative organization known as The Apple Breeder Cooperative (ABC), and workers in several other states have participated in testing selections. Introductions of the co-op selections and the release of scabimmune cultivars created great interest in the program throughout the world. Several countries, including Australia, Brazil, Canada, Czechoslovakia, England, France, Italy, Poland, South Africa, Romania, Sweden, and Russia, have incorporated PRI germplasm in their apple-breeding programs. By 2000, more than 50 scab resistant selections had been released.

\section{FUTURE PROSPECTS}

The excellent progress in developing new apple scab-immune cultivars was due to administrative support at the three institutions, the ability and willingness of the cooperating workers to pool their efforts and facilities, and the tremendous effort carried out in the Purdue University Department of Botany and Plant Pathology, under the guidance first of J.R. Shay and later of E.B. Williams, to carry out an efficient greenhouse screening procedure. About 380,000 seedlings were screened. Although the scab-resistance program still exists between the three institutions, activity has declined as the universities at each location reduced support. By 1993 the Department of Botany and Plant Pathology discontinued its input and I carried on the Purdue program, being directed to be concerned only with evaluating the remaining selections, although crossing continued. At the University of Illinois, Korban's program became oriented to the molecular biology of scab resistance. Screening has continued at Rutgers, but the apple-breeding program is just one small part of a general fruit-breeding program. However, just as the universities were fatigued with funding, a number of fruit growers became believers in the program and formed an organization called the Midwest Apple Improvement Association to continue the breeding efforts. Crosses have been made at Purdue and are supplied to the organization. Screenings in 1998, 1999, and 2000 were carried out by Diane Doud Miller at Ohio State University. At the same time, international interest in scab resistant breeding has continued in Europe.

\section{CONCLUSIONS}

The PRI program remains as an example of what can be accomplished in tree-fruit-breeding programs, long discounted for their slow progress, by a concerted attempt at transferring desirable genes from interspecific hybridization. Several serendipitous discoveries were made. By impatiently using the first fruiting selections from crosses as parents, reduced juvenility and increased precocity were selected. The advantages of diversity were demonstrated by the incorporation of a tolerance to a number of insects and diseases and long storage ability. The impact of the program is expected to be fully realized in the 21 st century, as more breeding programs worldwide incorporate this disease resistant material developed by the PRI program.

\section{Literature Cited and Further Reading}

Crandall, C.S. 1926. Apple breeding at the University of Illinois. Univ. Ill. (Urbana) Agr. Expt. Sta. Bul. 275.

Crosby, J.A., J.Janick, P.C.Pecknold, S.S. Korban, P.A. O'Conner, S.M. Ries, J. Goffreda, and A. Voordeckers. 1992. Breeding apples for scab resistance: 1945-1990. Fruit Var. J. 46:145-166.

Hough, L.F. 1944. A survey of the scab resistance of the foliage on seedlings in selected apple progenies. Proc. Amer. Soc. Hort. Sci. 4:260-272.

Janick, J. 2002. History of the PRI apple breeding program. Acta Hort. 595:55-59.

Janick, J., J.H.Cummins, S.K. Brown, and M. Hemmat. 1996. Apples, p. 1-77. In: J. Janick and J.N. Moore (eds.). Fruit breeding. Wiley, New York.

Parisi, L., Y. Lespinasse, J. Guillaumes, and J. Küger. 1993. A new race of Venturia inaequalis virulent to apples with resistance due to the $V f$ gene. Phytopathology 83:533-537.

PRI (Purdue Univ., Rutgers Univ., Univ. Illinois) disease resistant apple breeding program. www. hort.purdue.edu/newcrop/pri.

Shay, J.R. and L.F. Hough. 1952. Evaluation of apple scab resistance in selections in Malus. Amer. $\mathrm{J}$. Bot. 39:288-297.

Williams, E.B. and J. Kuc. 1969. Resistance in Malus to Venturia inaequalis. Annu. Rev. Phytopathol. 7:223-246. 